\title{
Management effects on soil carbon storage in New Zealand pastures
}

\author{
A.K. METHERELL \\ AgResearch, C/o Soil and Physical Sciences, P.O. Box 84, Lincoln University \\ alister.metherell@agr esearch.co.nz
}

\begin{abstract}
The amount of soil carbon is the net effect of carbon inputs and decomposition and is influenced by many factors including the level of herbage utilisation, root production, litter quality, soil fertility and soil moisture status. Long term experiments at Winchmore, in midCanterbury, show soil carbon levels increased after initial development, but after 50 years fertiliser input has had no net effect on soil carbon, while increasing the frequency of irrigation has actually resulted in lower soil carbon levels. Pasture development at Ballantrae, in the southern Hawke's Bay, has been associated with a decline in soil $\mathrm{C}$ levels, with the high fertility treatment having only slightly higher soil $\mathrm{C}$ than the treatment receiving a lower rate of fertiliser. At Tara Hills, in South Island semi-arid high country, increased stocking rate is associated with a decrease in soil C. Contrary to common perceptions increases in pasture and farm productivity do not necessarily result in increased soil carbon storage.
\end{abstract}

Keywords: carbon, fertiliser, grazing management, irrigation, soil organic matter

\section{Introduction}

Maintaining or increasing soil carbon (C) sequestration is important because of the New Zealand government's decision to ratify the Kyoto Protocol to the United Nations Framework Convention on Climate Change. Grassland soils cover approximately $59 \%$ of New Zealand's land area and contain an estimated $65 \%$ of total soil C (Scott et al. 2002). Pastoral management induced changes in soil $\mathrm{C}$ may be included under Article 3.4 of the Kyoto Protocol during the second commitment period. Whilst greenhouse gas mitigation policies adopted by the pastoral agricultural sector in New Zealand are likely to focus on mitigation of methane and nitrous oxide emissions, which make up almost half of the country's greenhouse gas emissions, it is very important that measures adopted do not adversely impact on soil C stocks. Of course, soil organic matter (SOM) is also important for the sustainability of agroecosystems, as it influences both chemical and physical soil properties and it plays a vital role in nutrient cycling.

The amount of soil $\mathrm{C}$, which is the net effect of $\mathrm{C}$ inputs and decomposition, is influenced by many factors including the level of herbage utilisation, root production, litter quality, soil fertility and soil moisture status. Pastoral management can directly and indirectly affect these factors. An increase in $\mathrm{C}$ sequestration is frequently associated with improved management of grassland (Conant et al. 2001). However, $\mathrm{C}$ levels in New Zealand pastoral soils are relatively high because of the continual inputs of large quantities of $\mathrm{C}$ from roots, senescent herbage and animal dung. Thus, there is much less potential for $\mathrm{C}$ sequestration than in many other countries where soils have been degraded as result of intensive arable agriculture.

An analysis of changes in soil $\mathrm{C}$ over 30 to 50 years for a large number of New Zealand grassland sites (Tate et al. 1997) found that on average there was no net change in soil $\mathrm{C}$ storage. Some sites increased while others decreased. Although much of New Zealand's soil C stocks appear to be close to a steady state (Tate et al. 1997), these stocks are very large, thus small relative changes in pasture land $\mathrm{C}$ density could be significant in relation to our Kyoto Protocol commitments (Baisden et al. 2001).

In New Zealand's intensive pastoral ecosystems a large proportion of the above ground net primary production is consumed by grazing livestock, with about $80 \%$ of the carbon ingested lost to the atmosphere through respiration and methane production. After allowing for animal growth and milk production, the remainder is returned to the soil as animal excreta, mostly in the form of dung. Carbon inputs to the soil also take the form of root exudates, dead roots, and senescent or trampled herbage. Thus the extent of pasture utilisation by livestock and factors affecting root growth are key determinants of carbon inputs.

This paper will focus on long-term field experiments at Winchmore, Ballantrae and Tara Hills where soil $\mathrm{C}$ storage has been measured under contrasting pastoral management treatments, including the effects of fertiliser, irrigation and stocking intensity.

\section{Winchmore irrigation and fertiliser experiments}

Over 50 years ago, field trials on grazed pasture were established at Winchmore Irrigation Research Station in mid-Canterbury, New Zealand on a Lismore stony 
silt loam soil to determine (i) the long-term $\mathrm{P}$ and $\mathrm{S}$ fertiliser requirements of irrigated pasture and (ii) the pasture response to various irrigation frequency regimes. Both experiments have been maintained and regular measurements continue to this day. The sites provide two of the best records of soil carbon dynamics and pastoral management effects available in New Zealand.

\section{Trial history}

The $\mathrm{P}$ and $\mathrm{S}$ fertiliser experiment (Nguyen et al. 1989) at Winchmore on grazed, border-strip irrigated pasture was initiated in 1952. The treatments include: i) Control, no fertiliser applied; ii) $188 \mathrm{~kg}$ single superphosphate/ha/yr; iii) $376 \mathrm{~kg}$ single superphosphate ha/yr. Lime was applied to the site in 1949,1950 (both $2.5 \mathrm{t} / \mathrm{ha}$ ) and in $1972(4.4 \mathrm{t} /$ ha). The site has not been cultivated since 1950 .

The long-term irrigation frequency experiment (Rickard \& McBride 1986) at Winchmore was initiated in 1949 on border-strip irrigated pasture. Irrigation treatments were changed in 1953 and 1958, but dryland plots have never been irrigated and the site has not been cultivated since 1958 . Treatments maintained since 1958 include: i) Dryland; ii) Irrigated at $10 \%$ soil moisture; iii) Ir rigated at $20 \%$ soil moisture. Approximately 100 $\mathrm{mm}$ of water is applied per irrigation application. Superphosphate has been applied at $250 \mathrm{~kg} / \mathrm{ha}$ to all treatments annually. Lime was applied in 1948 (5.0 t/ ha), 1953 (1.9 t/ha) and 1965 (4.1 t/ha).

\section{Results}

On each of the experiments distinct pastoral ecosystems have developed as a result of the longterm influence of management treatments. Superphosphate increased the proportion of white clover and decreased the proportion of weeds in the sward, while irrigation increased the proportion of white clover at the expense of subterranean clover. Both fertiliser and irrigation dramatically increased pasture production (Table 1).

There was an initial increase in soil $\mathrm{C}$ in the $\mathrm{P}$ and $\mathrm{S}$ fertiliser experiment at Winchmore from 1952 to 1963, irrespective of superphosphate application (Nguyen \& Goh 1990). This was associated with increased herbage production because of irrigation, pasture resowing and liming, and followed the effective loss of $\mathrm{C}$ in topsoil when the paddocks were border-dyked (using a grader). Over the initial period, soil $\mathrm{C}$ in the surface $7.5 \mathrm{~cm}$ in the fertilised treatments, increased from $2.7 \%$ to $3.7 \%$, a sequestration rate of $0.9 \mathrm{t} \mathrm{C} / \mathrm{ha} / \mathrm{yr}$. For the next 30 years soil $\mathrm{C}$ changed little with more surface soil $\mathrm{C}$ in treatments receiving superphosphate than in the unfertilised treatment (Nguyen \& Goh 1990). However by 1993 researchers (Murata et al. 1995; Olsen 1994) found that there was little difference in

Table 1 The effect of irrigation frequency and fertiliser rates at Winchmore, New Zealand on soil C (1997), pasture production (1952-2002), carbon allocation to roots, root production, mass and turnover, and shoot and root $\mathrm{N}$ and lignin contents.

\begin{tabular}{|c|c|c|c|c|c|c|c|c|}
\hline & Dryland & $\begin{array}{l}\text { Irrigated } \\
(10 \% \text { soil } \\
\text { moisture) }\end{array}$ & $\begin{array}{l}\text { Irrigated } \\
(20 \% \text { soil } \\
\text { moisture) }\end{array}$ & $\begin{array}{c}\text { LSD } \\
(P=0.05)\end{array}$ & $\begin{array}{c}\text { No } \\
\text { fertiliser }\end{array}$ & $\begin{array}{c}\text { Super- } \\
\text { phosphate } \\
(188 \mathrm{~kg} / \mathrm{ha} / \mathrm{yr})\end{array}$ & $\begin{array}{c}\text { Super- } \\
\text { phosphate } \\
(376 \mathrm{~kg} / \mathrm{ha} / \mathrm{yr})\end{array}$ & $\begin{array}{c}\text { LSD } \\
(P=0.05)\end{array}$ \\
\hline $\begin{array}{l}\text { Soil C \% } \\
\qquad(0-10 \mathrm{~cm})\end{array}$ & 4.20 & 4.16 & 3.59 & 0.19 & 3.65 & 3.79 & 3.64 & 0.23 \\
\hline $\begin{array}{l}\text { Soil C \% } \\
\quad(10-20 \mathrm{~cm})\end{array}$ & 2.59 & 2.64 & 2.30 & & 2.42 & 2.52 & 2.50 & \\
\hline $\begin{array}{l}\text { Soil } C\left(\mathrm{~g} / \mathrm{m}^{2}\right) \\
\quad(0-10 \mathrm{~cm})\end{array}$ & 5060 & 5020 & 4330 & 270 & 4420 & 4580 & 4390 & 270 \\
\hline $\begin{array}{r}\text { Soil C }\left(\mathrm{g} / \mathrm{m}^{2}\right) \\
(10-20 \mathrm{~cm})\end{array}$ & 3100 & 3150 & 2750 & & 2810 & 2930 & 2910 & \\
\hline $\begin{array}{l}\text { Pasture production } \\
\text { (t DM/ha/yr) }\end{array}$ & 7.1 & 10.2 & 12.2 & 0.4 & 4.8 & 10.9 & 11.9 & 0.9 \\
\hline $\begin{array}{l}\text { Allocation of } C \text { to } \\
\text { roots }(\%)\end{array}$ & 36 & - & 35 & 10 & 40 & - & 35 & 5 \\
\hline $\begin{array}{l}\text { Root production } \\
\text { (t DM ha/yr) }\end{array}$ & 4.3 & - & 4.6 & 0.8 & 4.2 & - & 4.9 & 2.2 \\
\hline $\begin{array}{l}\text { Root mass } \\
\text { (t DM/ha) }\end{array}$ & 7.7 & - & 6.0 & 1.3 & 7.0 & - & 5.9 & 0.9 \\
\hline $\begin{array}{l}\text { Root turnover time } \\
\text { (years) }\end{array}$ & 2.0 & - & 1.3 & 0.4 & 1.9 & - & 1.3 & 0.7 \\
\hline Shoot N (\%) & 2.9 & - & 2.8 & 0.5 & 1.5 & - & 2.5 & 0.7 \\
\hline Shoot lignin (\%) & 4.1 & - & 2.8 & 1.0 & 4.7 & - & 2.8 & 1.7 \\
\hline Root N (\%) & $1.2-$ & 1.1 & 0.2 & 0.8 & - & 1.2 & 0.3 & \\
\hline Root lignin (\%) & 10.0 & - & 8.6 & 1.9 & 11.2 & - & 10.1 & 3.0 \\
\hline
\end{tabular}


soil $\mathrm{C}$ between treatments. A trend for the $188 \mathrm{~kg}$ superphosphate ha/yr treatment to have more soil C than the 0 and $376 \mathrm{~kg}$ superphosphate ha/yr treatments is apparent in $0-7.5 \mathrm{~cm}$ samples from 1993 to 2001 (Mean soil C for 4 sampling dates: $3.95,4.13,3.94 \% \mathrm{C}$ for 0,188 and $376 \mathrm{~kg}$ superphosphate/ha/yr respectively; $\operatorname{LSD}_{0.05} 0.17 \%$ ). This result could be because of under-utilisation of herbage by stock on the $188 \mathrm{~kg}$ superphosphate ha/ yr treatment (the stocking rate on this treatment was reviewed in 1996 and increased). However Stewart \& Metherell (1999a) found no significant differences between treatments in soil $\mathrm{C}$ at $0-10 \mathrm{~cm}$ and 10-20 cm depths in 1997 (Table 1). There were no irrigation or fertiliser effects on soil bulk density at Winchmore (Stewart \& Metherell 1999a), so differences in soil $\mathrm{C}$ between treatments would be proportionately similar whether expressed as a percentage or on an area basis.

On the Winchmore ir rigation experiment analyses of soil $\mathrm{C}$ from around 1970 and in the last 5 years have consistently shown a trend of highest $\mathrm{C}$ levels in the dryland treatment and significantly lower $\mathrm{C}$ levels in the most frequently irrigated treatment (20\% soil moisture) (Metherell et al. 2002; Stewart \& Metherell 1999a; Table 1), despite the increased herbage production with increasing irrigation frequency (Table 1).

The soil carbon results in both Winchmore experiments are contrary to the common perception that SOM increases with increasing herbage production. Root production is an important factor influencing soil $\mathrm{C}$ in grazed pastoral ecosystems. It appears that plants under moisture or nutrient stress have larger root systems that turnover more slowly (Table 1). This, in part, results from the greater proportional allocation of $\mathrm{C}$ to plant roots in the absence of superphosphate (Stewart \& Metherell 1999b; Table 1). The rate of root turnover, estimated from the time for pulse labelled ${ }^{13} \mathrm{C}$ in roots to dissipate through root respiration, death and decomposition (Stewart \& Metherell 1998), was slower in the absence of irrigation and superphosphate compared with the $20 \%$ irrigation and $376 \mathrm{~kg}$ superphosphate ha/yr treatments (Table 1). However root production, a function of root mass and turnover time, was very similar for all treatments at Winchmore (Table 1). Plant material with a high lignin content in the low fertility and unirrigated treatments, and a low $\mathrm{N}$ concentration in the unfertilised treatment (Table 1) will decompose more slowly (Parton et al. 1987). Differences in the quality of plant herbage and roots arise from both the direct effects of nutrient availability, and the influence of nutrient availability on botanical composition. The decomposition rate would also be slower because of the lower earthworm biomass when superphosphate was not applied (Fraser et al. 1994) and in the absence of irrigation (Fraser \& Piercy 1996).

The higher average soil moisture status of the frequently irrigated treatment will result in an increase in average soil carbon mineralisation rates. Incubation of soils from the Winchmore irrigation trial has shown that at field capacity labile carbon is initially mineralised at a similar rate in dryland and irrigated soils, but that over a longer period the mineralisation rate reflects the differences in total soil C (unpublished data).

Ballantrae hill country fertiliser experiment The effect of two fertilizer treatments on SOM were measured from 1972 to 1987 , within ten grazed permanent-pasture farmlets, on steep hill country on Ballantrae Research Station in southern Hawke's Bay, New Zealand (Lambert et al. 2000). Superphosphate was applied to the whole area at 125 $\mathrm{kg} / \mathrm{ha} / \mathrm{yr}$ in 1973 and 1974, with different rates applied from 1975. Over the first 5 years the low treatment received a total of $55 \mathrm{~kg} \mathrm{P} / \mathrm{ha}$, while the high fertiliser treatment received $303 \mathrm{~kg} \mathrm{P} / \mathrm{ha}$. From 1977 the low fertilizer treatment received superphosphate at $125 \mathrm{~kg} / \mathrm{ha} / \mathrm{yr}$, and from 1980 the high fertilizer treatment received $375 \mathrm{~kg} / \mathrm{ha} / \mathrm{yr}$. Ground limestone was applied to the high fertiliser treatment in 1975 (1.25 t/ha) and 1979 (2.5 t/ha). By 1986 the low and high fertiliser treatments were carrying 12.0 and 17.2 ewe equivalents/ha, respectively, with similar levels of grazing pressure on both treatments.

Soil C declined in both treatments by about $200 \mathrm{~kg}$ $\mathrm{C} / \mathrm{ha} / \mathrm{yr}$ from an average of $5.44 \% \mathrm{C}(0-7.5 \mathrm{~cm})$ in 1972 to $4.79 \% \mathrm{C}$ in 1986 (5.05\%C in 1987). Despite the large difference in pasture and animal production, the high fertility treatment had only slightly higher soil C. As at Winchmore, there was a greater allocation of photosynthate to pasture roots in the low fertility treatment than under high fertility (Saggar et al. 1997), and the results also suggest a more rapid turnover of soil $\mathrm{C}$ with high fertility. Lambert et al. (2000) postulated that the decline in soil $\mathrm{C}$ may be due to the change from a forest to a grassland ecosystem. However, Clark et al. (2001) reanalysed the Ballantrae soil $\mathrm{C}$ data and suggested that the decline in soil $\mathrm{C}$ could mainly be due to the increase in stock carrying capacity over time, with an increased proportion of net primary production being consumed by animals and lost to the 
atmosphere through respiration and methanogenesis.

\section{Tara Hills high country grazing management experiment}

Direct evidence of a stocking rate effect on SOM is seen on a long-term experiment on a steep, oversown tussock site at Tara Hills High Country Research Station in the semi-arid (approx. $500 \mathrm{~mm}$ precipitation/yr) high country $(910 \mathrm{~m}$ above sea level) of the South Island, New Zealand (Allan et al. 1992). The site is steep $\left(27^{\circ}\right)$ and contains indigenous short tussock species as well as improved legumes and grasses from oversowing. It has been fertilised with both $\mathrm{P}$ and $\mathrm{S}$ periodically since 1965. Treatments are continuous, alternating (two paddock system) or rotational (six paddock system) grazing with $1.9,3.0$ or 4.1 sheep/ha during summer months. The experiment began in 1978, has a plot size of 1.7 ha and is unreplicated. The initial soil sampling in 1979 was of upper, mid and lower slope areas in the continuous treatment. In 1984 and 2003 intensive soil samplings of seven altitudinal strata within each plot were conducted. From 1996 to 1999 detailed studies of carbon cycling were conducted on the continuous and alternating grazing management treatments at three stocking rates. For statistical purposes the stocking rate by grazing management interaction is used as the error term, which gives a conservative assessment of statistical significance. For the 1984 and 2003 results a stocking rate by grazing management interaction term was estimated from the interaction of two orthogonal contrasts, with the remaining interaction terms used as the error term (Allan 1985).

With pasture development, in a tussock grassland environment, soil $\mathrm{C}$ levels have in most treatments at least been maintained or possibly increased. In the 2003 soil sampling higher soil C levels were found in the stock camp zones at the upper part of each
Table 2 The effect of grazing management and sheep stocking rate at Tara Hills on soil C (\%). Mean of 6 altitudinal strata, excluding stock camps, sampled May 2003 and April 1984 (Allan 1985) and mean of 3 altitudinal strata in continuous grazing plots, sampled January 1979 (Allan 1985). LSD $(P=0.05)$ for interaction terms $=$ 0.715 ; for 2003 main effects $=0.413$; for 1984 main effect $=0.3$.

\begin{tabular}{lrrrr}
\hline Grazing & \multicolumn{3}{c}{ Stocking rate -} & \\
\cline { 2 - 4 } management & Low & Medium & High & Mean \\
\hline Continuous & 3.82 & 3.22 & 2.73 & 3.26 \\
Alternating & 3.56 & 3.28 & 3.12 & 3.32 \\
Rotational & 3.38 & 3.11 & 2.95 & 3.15 \\
Mean (2003) & 3.59 & 3.20 & 2.94 & 3.24 \\
1979 Continuous & 3.6 & 3.1 & 3.3 & \\
1984 Mean & 2.7 & 2.5 & 2.4 & 2.6 \\
\hline
\end{tabular}

paddock of all treatments, but an altitudinal trend had not been observed for soil C in 1984 (Allan 1985). In 2003, the lower stocking rate resulted in significantly higher soil C concentrations (Table 2), primarily because of high soil $\mathrm{C}$ levels in laxly grazed areas in the lowest altitudinal strata of some low stocking rate treatments. Over all altitudes the stocking rate effect was most pronounced in the continuous grazing management treatment, with the highest soil $\mathrm{C}$ levels found in the low stocking rate continuous grazing treatment, and the lowest soil $\mathrm{C}$ levels in the overgrazed high stocking rate continuous treatment. Although an effect of stocking rate was apparent in an initial pre-treatment sampling of the continuous treatment plots in 1979, and in the 1984 results (Allan 1985) the magnitude of the effect has increased with time. Similar trends were observed in two samplings in 1997, particularly in the surface $10 \mathrm{~cm}$, although the effect did not reach statistical significance (Stewart \& Metherell 2001; Table 3). Although the proportion of $\mathrm{C}$ allocated to roots increased with increasing stocking rate (Table 3 ), no significant differences in root production were found. Decreasing tussock content with increased

Table 3 The effect of sheep stocking rate at Tara Hills on soil C (1997), pasture production (1981-1984) and root measurements made under tussock and inter-tussock vegetation.

\begin{tabular}{|c|c|c|c|c|c|}
\hline & & $\begin{array}{c}1.9 \\
\text { sheep/ha }\end{array}$ & $\begin{array}{c}3.0 \\
\text { sheep/ha }\end{array}$ & $\begin{array}{c}4.1 \\
\text { sheep/ha }\end{array}$ & $\begin{array}{c}\text { LSD } \\
(P=0.05)\end{array}$ \\
\hline Soil C \% $(0-10 \mathrm{~cm})$ & & 5.5 & 4.9 & 3.6 & 3.1 \\
\hline Soil C \% (10-20 cm) & & 3.1 & 2.9 & 2.6 & \\
\hline Soil C $\left(\mathrm{g} / \mathrm{m}^{2}\right)(0-10 \mathrm{~cm})$ & & 4600 & 4170 & 3420 & 2160 \\
\hline Soil C $\left(\mathrm{g} / \mathrm{m}^{2}\right)(10-20 \mathrm{~cm})$ & & 3710 & 3550 & 2960 & \\
\hline $\begin{array}{l}\text { Pasture production } \\
\text { (mean 1981-84) (t DM ha/yr) }\end{array}$ & & 1.87 & 2.05 & 2.14 & - \\
\hline Allocation of $\mathrm{C}$ to roots (\%) & Inter-tussock:tussock & 28:24 & 40:30 & $45: 38$ & 9 \\
\hline Root production(t DM ha/yr) & Inter-tussock:tussock & $1.39: 1.21$ & 2.64:1.97 & $2.44: 0.89$ & 1.67 \\
\hline Root mass(t DM/ha) & Inter-tussock:tussock & $3.6: 5.2$ & $4.2: 6.1$ & $2.4: 6.4$ & 4.7 \\
\hline Root turnover time (years) & Inter-tussock:tussock & $3.8: 2.8$ & 2.3:2.1 & $2.6: 2.9$ & 1.4 \\
\hline
\end{tabular}


stocking rate (Allan et al. 1992) is reflected in the trend of a reduction in tussock root mass, which is compensated by an increase in the inter-tussock root mass. There was no clear trend in root turnover time. It appears that the lower soil $\mathrm{C}$ levels with a higher stocking rate are largely due to a reduction in litter inputs resulting from increased herbivory. A similar result was noted by Hoglund (1985) in a shorterterm experiment at Kirwee in Canterbury.

\section{Conclusion}

Carbon levels in New Zealand pastoral soils are relatively high because of the continual inputs of carbon from roots, senescent herbage and animal dung. The amount of soil carbon is the net effect of carbon inputs and decomposition and is influenced by many factors including the level of herbage utilisation, root production, litter quality, soil fertility and soil moisture status. Pastoral management can directly and indirectly affect these factors.

At Winchmore, soil C increased dramatically after initial development, but after 50 years different levels of fertiliser input have had no net effect on soil $\mathrm{C}$, while a high irrigation frequency has actually resulted in lower soil C levels. Treatment effects on root production, litter quality, earthworm activity, and mineralisation rates have all been shown to contribute to the observed effects on soil C. At Ballantrae a gradual decline in soil $\mathrm{C}$ at both high and low fertility, may be associated with a long term transition from a previously forested soil to a pasture, or with an increase in stocking rate and pasture utilisation as pasture development proceeded. However with pasture development in a tussock grassland at Tara Hills, soil C levels have generally been maintained with evidence of soil $\mathrm{C}$ sequestration in stock camps, and at low stocking rates, especially in laxly grazed areas or with continuous grazing management.

Contrary to common perceptions increases in pasture and farm productivity do not necessarily result in increased soil carbon storage.

\section{ACKNOWLEDGEMENTS}

I am indebted to the scientists and technicians who initiated and maintained the long-term experimental sites described in this paper. The ${ }^{13} \mathrm{C}$ pulse labelling experimental work at Winchmore and Tara Hills and associated sampling of soils and plant material was conducted by the late Dr D.P.C. Stewart.

\section{REFERENCES}

Allan, B.E. 1985. Grazing management of oversown tussock grassland in the South Island high country.
PhD thesis, University of Canterbury.

Allan, B.E.; O’Connor, K.F.; White, J.G.H. 1992. Grazing management of oversown tussock country.

2. Effects on botanical composition. New Zealand Journal of Agricultural Research 35: 7-19.

Baisden, W.T.; Beets, P.; Carran, R.A.; Clark,H.; FordRobertson, J.B.; Francis, G.S.; Maclaren, P.; Marshall, H.; Manning, M.R.; Newton, P.C.D.; Saggar, S.; Tate, K.R. 2001. An Assessment of The Significance To New Zealand Of Article 3.4 Activities Under The Kyoto Protocol. A Report Prepared for Ministry for Agriculture and Forestry. 8 June 2001. http://www.maf.govt.nz/mafnet/ruralnz/sustainable-resource-use/climate/sinks-activities/ httoc.htm.

Clark, H.; de Klein, C.; Newton, P. 2001. Potential management practices and technologies to reduce nitrous oxide, methane and carbon dioxide emissions from New Zealand agriculture. Prepared for Ministry of Agriculture \& Forestry. September 2001. http://www.maf.govt.nz/mafnet/publications/ climate/green-house-gas-migration/ghgmitigation.pdf.

Conant, R.T.; Paustian, K.; Elliott, E.T. 2001. Grassland management and conversion into grassland: effects on soil carbon. Ecological Applications 11: 343-355.

Fraser, P.M.; Haynes, R.J.; Williams, P.H. 1994. Effects of pasture improvement and intensive cultivation on size of microbial biomass, enzyme activities and composition and size of earthworm populations. Biology and Fertility of Soils 17: 185190.

Fraser, P.M.; Piercy, J.E. 1996. Effects of summer irrigation on the seasonal activity, population size, composition and biomass of lumbricid earthworms in a long-term irrigation trial at Winchmore, New Zealand. pp. 89-90. In: ASSSI and NZSSS National Soils Conference1996. Volume 2.

Hoglund, J.H. 1985. Grazing intensity and soil nitrogen accumulation. Proceedings of the New Zealand Grassland Association 46: 65-69.

Lambert, M.G.; Clark, D.A.; Mackay, A.D .; Costall, D.A. 2000. Effects of fertiliser application on nutrient status and organic matter content of hill soils. New Zealand Journal of Agricultural Research 43: 127-138.

Metherell, A.K.; Stewart, D.P.C.; Carey, P.L.; Moss, R.A. 2002. Long-term irrigation improves soil quality, but decreases soil carbon sequestration. pp. 55-61 In: Soil Quality and Sustainable Land Management Conference. April 3-5, 2002. Eds. Stephens, P; Callaghan, J.; Austin, A. Landcare Research New Zealand Ltd. 
Murata, T.; Nguyen, M.L.; Goh, K.M. 1995. The effects of long-term superphosphate application on soil organic matter content and composition from an intensively managed New Zealand pasture. European Journal of Soil Science 46: 257-264.

Nguyen, M.L.; Goh, K.M. 1990. Accumulation of soil sulphur fractions in grazed pastures receiving long-term superphosphate applications. New Zealand Journal of Agricultural Research 33: 111-128.

Nguyen, M.L.; Rickard, D.S.; McBride, S.D. 1989. Pasture production and changes in phosphorus and sulphur status in irrigated pastures receiving long-term applications of superphosphate fertiliser. New Zealand Journal of Agricultural Research 32: 245-262.

Olsen, C.D. 1994. The effect of soil fertility on organic matter fractions in a pastoral soil. B. Hort. Sc (Hons.) dissertation. Lincoln University.

Parton, W.J.; Schimel, D.S.; Cole, C.V.; Ojima, D.S 1987. Analysis of factors controlling soil organic matter levels in Great Plains grasslands. Soil Science Society of America Journal 51: 11731179.

Rickard, D.S.; McBride, S.D. 1986. Irrigated and non-irrigated pasture production at Winchmore 1960 to 1985. Winchmore Irrigation Research Station Technical Report 21.

Saggar, S.; Hedley, C.; Mackay, A.D. 1997. Partitioning and translocation of photosynthetically fixed $\mathrm{C}$ in grazed hill pastures. Biology and Fertility of Soils 25: 152-158.
Scott, N.A.; Tate, K.R.; Giltrap, D.J.; Smith, C.T.; Wilde, R.H.; Newsome, P.F.J.; Davis, M.R. 2002. Monitoring land-use change effects on soil carbon in New Zealand: quantifying baseline soil carbon stocks. Environmental Pollution 116: S167-S186.

Stewart, D.P.C.; Metherell, A.K. 1998. Using ${ }^{13} \mathrm{C}$ pulse labelling to investigate carbon cycling in pastoral ecosystems. In: 16th World Congress of Soil Science. Cirad. CD-ROM.

Stewart, D.P.C.; Metherell, A.K. 1999a. Long-term influence of management practices on the soil carbon of pastoral ecosystems. In: Best Soil Management Practices for Production. (Eds. Currie, L.D., Hedley, M.J., Horne, D.J., Loganathan, P.) Occasional report No. 12 Fertilizer and Lime Research Centre, Massey University, Palmerston North. pp 317-326.

Stewart, D.P.C.; Metherell, A.K. 1999b. Carbon $\left({ }^{13}\right.$ C) uptake and allocation in pasture plants following field pulse labelling. Plant and Soil 210: 61-73.

Stewart, D.P.C.; Metherell, A.K. 2001. Influence of 20 years of different sheep grazing intensities and managements on soil organic matter quality in high country pastoral ecosystems; South Island, New Zealand. pp. 257-262 In: Understanding and managing organic matter in soils, sediments and waters. Eds. Swift, R.S.; Spark, K.M. International Humic Substances Society, St. Paul.

Tate, K.R.; Giltrap, D.J.; Claydon, J.J.; Newsome, P.F.; Atkinson, I.A.E.; Taylor, M.D.; Lee, R. 1997. Organic carbon stocks in New Zealand's terrestrial ecosystems. Journal of the Royal Society of New Zealand 27: 315-335. 